\begin{tabular}{|c|c|}
\hline Title & $\begin{array}{l}\text { Parentage assignment of stocked black sea bream A canthopagrus schlegelii in Hiroshima Bay using microsatellite DNA } \\
\text { markers }\end{array}$ \\
\hline Author(s) & Jeong, Dal-Sang; Gonzalez, Enrique Blanco; Morishima, Kagay aki; A rai, Katsutoshi; Umino, Tetsuya \\
\hline Citation & $\begin{array}{l}\text { Fisheries Science, 73(4), } 823-830 \\
\text { https://doi.org/10.1111j.1444.2906.2007.01402.x }\end{array}$ \\
\hline Issue Date & $2007-08$ \\
\hline Doc URL & http:/hdl .handle.net/2115/35581 \\
\hline Rights & ○ 2007 公益社団法人日本水産学会; @ 2007 The Japanese Society of Fisheries Science \\
\hline Type & article \\
\hline File Information & 2007-73_p823-830.pdf \\
\hline
\end{tabular}

Instructions for use 


\title{
Parentage assignment of stocked black sea bream Acanthopagrus schlegelii in Hiroshima Bay using microsatellite DNA markers
}

\author{
Dal-Sang JEONG, ${ }^{1,2}$ Enrique Blanco GONZALEZ, ${ }^{1}$ Kagayaki MORISHIMA, ${ }^{3}$ Katsutoshi ARAI ${ }^{3}$ \\ AND TETSUYA UMINO ${ }^{1 *}$
}

\begin{abstract}
${ }^{1}$ Graduate School of Biosphere Sciences, Hiroshima University, Higashi-Hiroshima, Hiroshima 739-8528, Japan, ${ }^{2}$ Marine Seed Releasing Technology Center, Wando 537-806, South Korea, and ${ }^{3}$ Graduate School of Fisheries Sciences, Hokkaido University, Hakodate, Hokkaido 041-8611, Japan
\end{abstract}

\begin{abstract}
The genetic contribution of 51 broodstock, comprising 29 females and 22 males, reared at Hiroshima City Marine Products Promotion Center for the production of stocked black sea bream was monitored during two consecutive years using seven microsatellite DNA loci. The high discrimination ability of these markers was reflected in the polymorphic identification content $(P I C=0.831)$, the exclusion probability $(Q \sim 1)$, and the low probability of identity index $\left(I=3.635^{-10}\right)$. The total number of breeders contributing to the mating process was estimated at $32(62.7 \%)$ in 2000 and $30(58.8 \%)$ in 2001 . On pedigree reconstruction, $69.3 \%$ of the offspring were successfully assigned to a single broodstock pair. Loss of alleles accounted for $16.9 \%$ during seed production; nevertheless, $90.9 \%$ of males and $69.0 \%$ of females participated in the mating process. Based on microsatellite genetic tagging, $58.9 \%$ of the fish sampled during the two months after release were identified as hatchery stock, presenting no significant differences from wild conspecifics in either fork length or body weight.
\end{abstract}

KEY WORDS: Acanthopagrus schlegelii, black sea bream, genetic tagging, microsatellite DNA, parentage analysis, stock enhancement.

\section{INTRODUCTION}

Black sea bream Acanthopagrus schlegelii is widely distributed from the South China Sea to the coastal waters of Japan and Korea. In Japan, black sea bream is an important resource for sport and commercial fisheries, with around 6 million fingerlings artificially stocked annually. ${ }^{1}$ Although survival and acclimation of released fingerlings into the natural environment were well documented, ${ }^{2-4}$ knowledge concerning genetic aspects is still limited.

Many authors warned of the reduction in genetic variability derived from limited numbers of breeders under hatchery conditions. ${ }^{5-9}$ The genetic drift might induce a smaller growth and survival, as well as increase the susceptibility to diseases in offspring. ${ }^{10}$ Recent studies assessing the genetic

*Corresponding author: Tel: 81-824-24-7944.

Fax: 81-824-24-7944. Email: umino@hiroshima-u.ac.jp

Received 4 August 2006. Accepted 16 March 2007. diversity of stocked sparidae have demonstrated the strength of microsatellite DNA over previous techniques using proteins. ${ }^{11-13}$ Moreover, the high polymorphism screened by microsatellites results is very useful to examine consanguineous strains. Parentage assignment using a few numbers of microsatellite DNA markers has been evidenced in some of the most important fish species for stocking and cultivation. ${ }^{8,14-16}$

In Hiroshima Prefecture, western Japan, the catch of black sea bream accounted for $15 \%$ of the total black sea bream catch in Japan. Hiroshima Bay is known as the main fishing ground with $60 \%$ of the catch in the Prefecture. The recent increment in the volume of landings of this fish seems to be linked to the intensive stocking practices in the area since 1982. Therefore, genetic monitoring of released black sea bream is necessary to preserve and manage the genetic resources efficiently.

Two main objectives were achieved in the present study. First, in order to assess the genetic variability between breeders and stocked black sea 
Table 1 Core repeats, primers sequences and annealing temperature of microsatellite loci in black sea bream

\begin{tabular}{|c|c|c|c|c|}
\hline Locus & Core repeat sequences & Primer sequences $\left(5^{\prime}\right.$ to $\left.3^{\prime}\right)$ & $\operatorname{Tm}\left({ }^{\circ} \mathrm{C}\right)$ & GenBank accession No. \\
\hline ACS3 & $(\mathrm{CA})_{16}$ & $\begin{array}{l}\text { F: GGACCCATATGTCTGTCAAA } \\
\text { R: TTTATGAGCGACCCTGAGTC }\end{array}$ & 57 & AB095008 \\
\hline$A C S 4$ & $(G T)_{12}$ & $\begin{array}{l}\text { F: TTTACACACCGGGAGCTCAA } \\
\text { R: GTAAAGATCCATGGAGGTGC }\end{array}$ & 57 & AB095009 \\
\hline ACS6 & $(\mathrm{GT})_{12}$ & $\begin{array}{l}\text { F: GTCTGACATCATGCTCTGAG } \\
\text { R: ACAACCGTCTTCTTCTTACG }\end{array}$ & 56 & AB095010 \\
\hline ACS9 & $(\mathrm{CA})_{21}$ & $\begin{array}{l}\text { F: GAACTGACAGTAGTGACTGG } \\
\text { R: GTGCTGCAGTTTATATCTGC }\end{array}$ & 56 & AB095011 \\
\hline ACS16 & $(\mathrm{CA})_{28}$ & $\begin{array}{l}\text { F: ACCAAGGACCCTTGTGAATG } \\
\text { R: GCATGTCTGCAGCAACAGCA }\end{array}$ & 53 & AB095012 \\
\hline ACS17 & $(\mathrm{CA})_{24}$ & $\begin{array}{l}\text { F: ACAGGCGCATGTGTTTATGC } \\
\text { R: ATCTCTCCGTATCTTCCTCC }\end{array}$ & 64 & AB095013 \\
\hline ACS21 & $(\mathrm{CA})_{12}$ & $\begin{array}{l}\text { F: CGGAAAGGAAGCAGCTCTTG } \\
\text { R: AACTGTTAGCCAGGGTCAGC }\end{array}$ & 64 & AB095014 \\
\hline
\end{tabular}

Tm, annealing temperature.

bream juveniles and its potential effect on natural populations, the contribution of the broodstock was assessed by tracing the pedigree of fingerlings during two consecutive years based on microsatellite DNA markers. Second, the effectiveness of the stocking program during the critical postrelease period was investigated by identifying stocked juveniles at a small cove of Ninoshima Island in Hiroshima Bay by using microsatellite-based genetic tagging.

\section{MATERIALS AND METHOD}

\section{Broodstock and offspring}

This study was conducted under standard seed production and stock enhancement procedures. The broodstock comprised 29 dams and 22 sires originating from wild captives, and hatchery strains. Fish were accommodated at Hiroshima City Marine Products Promotion Center in 2000 and 2001. The same breeders were maintained during the two consecutive years of study without individual replacement or mortality. Sex of each breeder was checked by spermiation or oviposition after squeezing the abdomen gently in June 2000 . All broodstock presented longer than $330 \mathrm{~mm}$ in body length, rejecting any possibility of sex change in this protandrous hermaphrodite species.

According to routine seed production, the mesocosm spawning method was used to collect fertilized eggs in one night during the spawning peak in May 2000 and 2001. Larvae were reared under routine hatchery condition. For pedigree tracing, 70 offspring in 2000 and 110 in 2001 of 3 months of age were randomly collected just before release.
In addition, 20000 juveniles were stocked in Ninoshima Island in 2001 and then subjected to a release-recapture experiment for the stock separation study in the present work.

\section{DNA extraction and detection of microsatellite loci}

The pectoral fin from each of the 51 breeders was partially clipped, and inserted into $95 \%$ ethanol for DNA extraction in 2001. Muscle tissue of offspring and wild fish were stored at $-80^{\circ} \mathrm{C}$. DNA extraction was carried out by the standard SDS-phenolchloroform procedure. ${ }^{17}$ Microsatellite analysis was performed using seven loci of dinucleotide (CA/GT) repeats described in Table 1 . Besides three loci, ACS3, ACS6, and ACS9 isolated in a previous study, ${ }^{11}$ four microsatellite loci, ACS4, ACS16, $A C S 17$, and $A C S 21$ were newly isolated. Briefly, genomic DNA was digested with Sau 3AI and DNA fragments ranging $400-600$ bp were selected on agarose gel. The size-selected fragments were ligated into the BamHI site of pUC18 plasmid vector. Positive transformations were screened by the chemiluminescence method with $(\mathrm{CA})_{10}$ synthetic biotinylated oligonucleotide. Positive clones were sequenced using an Abiprism 377 genetic analyzer (Applied Biosystems, Foster City, CA, USA).

In every set of primers, the $5^{\prime}$ end of the reverse primer was labeled with biotin. Polymerase chain reactions (PCRs) were prepared using Taq polymerase (TaKaRa, Shiga, Japan) and carried out in a GeneAmp PCR System 9700 instrument (Applied Biosystems). The PCR program consisted of one denaturation at $95^{\circ} \mathrm{C}$ for $1.5 \mathrm{~min}$ followed by 35 
cycles of $30 \mathrm{~s}$ at $95^{\circ} \mathrm{C}, 1 \mathrm{~min}$ at annealing temperatures given in Table $1,30 \mathrm{~s}$ at $72^{\circ} \mathrm{C}$, and a final extension of $2 \mathrm{~min}$ at $72^{\circ} \mathrm{C}$. Each PCR product was electrophoresed in $8 \%$ polyacrylamide gel $(7 \mathrm{M}$ urea, $8 \%$ polyacrylamide). Afterwards, amplified DNA fragments were transferred to a nylon membrane, and detected by chemiluminescence (Sequencing High-Cycle, Toyobo, Osaka, Japan) with pUC18 ssDNA as sequencer ladder.

\section{Genetic variability}

The genetic variability among black sea bream samples was assessed through the number of alleles per locus and the observed and expected heterozygosities $(\mathrm{Ho}, \mathrm{He})$ using GENEPOP v3.4 software. ${ }^{18}$ Deviations from Hardy-Weinberg equilibrium (HWE) at each locus were estimated using a test analogous to Fisher's exact test, with a modified version of the Markov chain method ( $10^{5}$ steps and $10^{4}$ dememorizations), ${ }^{19}$ performed with the Arlequin v2.0 package. ${ }^{20}$ A linkage disequilibrium test of non-random association of alleles at different loci and allele frequency at each locus was tested by analysis of molecular variance (AMOVA). ${ }^{20}$

\section{Microsatellite discrimination power}

The discrimination ability of microsatellite DNA markers for pedigree reconstruction was assessed estimating the polymorphic information content $(P I C)$ in the broodstock ${ }^{21}$ by using Cervus 2.0 software. ${ }^{22}$ The probability of excluding a parental pair from a randomly chosen offspring given by the exclusion probability $(Q)^{23}$ was also calculated. In addition, in order to avoid offspring-broodstock mismatching, the probability of identity index $(I)$ applied to red sea bream Pagrus major ${ }^{24}$ was determined.

\section{Parentage matching and pedigree analysis}

Parentage assignment was partly supported by PAPA software. ${ }^{25}$ The best match between the genotypes of the offspring and the broodstock at all loci was confirmed by manual operation. The effective number of parents $(\mathrm{Ne})$ was estimated after correcting the effects of different sex ratio in the breeders, ${ }^{26}$ and family size differences, ${ }^{27}$ resulting in $N e^{*}=8 \times N e /\left(4+V_{k f}+V_{k m}\right)$, where $V_{k f}$ and $V_{k m}$ are the variances in family size among females and males, respectively. The inbreeding coefficient $(F)$ is expressed as $F=0.5 \times N e^{*}$.

\section{Stock separation}

From the release-recapture experiment on 29 July 2001, 20000 juveniles were stocked at a small cove (Daio Bay) in Ninoshima Island at Hiroshima Bay. A map showing the locality of releasing site has been presented elsewhere. ${ }^{2}$ In order to assess the recapture rate of released juveniles, 199 fish were collected using a throw net at the releasing area from 30 July-28 September. Stock discrimination between wild and hatchery fish was conducted using five microsatellite DNA markers (ACS3, ACS4, ACS6, ACS9, and ACS16). Variations in fork length (FL, mm) and body weight (BW, g) between release-recaptured and wild fish were analyzed.

\section{RESULTS}

\section{Genetic variability and pedigree analysis}

On changes in genetic variability between the broodstock and their offspring in 2000 and 2001 (Table 2), the number of alleles per locus in the present study ranged 7-18. The broodstock averaged 13.3, with mean values of 11.1 and 11.0 in 2000 and 2001 offspring, respectively. Ho averaged 0.846 , 0.844 , and 0.854 for the same three groups, revealing deviations from HWE in the offspring of 2001 at two loci. Despite no significant difference $(P<0.05)$ in allele frequencies, loss of alleles through seed production was detected $16.9 \%$ on average.

The discrimination power of microsatellites for parentage analysis, the exclusion probability, reached approximately 1 using only five loci (Table 3). PIC with 0.831 on average at all loci could confirm the proper assignment of the progeny. In addition, the probability of finding two offspring sharing the same genotype at all loci is limited to less than $1 \times 10^{-9}\left(I=2.980 \times 10^{-10}, I=4.290 \times 10^{-10}\right.$, in 2000 and 2001, respectively).

The pedigree analysis successfully assigned $69.3 \%$ of the offspring $(69.7 \%$ in 2000 and $69.0 \%$ in 2001 ) to a single parental couple (Table 4 ). The reconstructed mating model (Fig. 1) compiles the total of 36 and 40 families identified in 2000 and 2001, respectively. Female \#23 mated seven males in 2000, and male \#49 constituted eight families each year; these fish were the most active breeders.

The number of contributors was estimated at 32 $(62.7 \%)$ in 2000 and 30 (58.8\%) in 2001. Progenies from 20 dams $(69.0 \%)$ and 20 sires $(90.9 \%)$ were identified within the two years studied. Balance in the sex proportion among breeders was observed; however, differences in the family sizes caused the final effective population sizes $(\mathrm{Ne})$ to be reduced to 19.8 (38.1\%) and $8.9(70.3 \%)$ in 2000 and 2001, 
Table 2 Genetic diversity of broodstock and offspring in 2000 and 2001 at seven loci

\begin{tabular}{|c|c|c|c|c|c|c|c|c|}
\hline & ACS3 & ACS4 & ACS6 & ACS9 & ACS16 & $A C S 17$ & ACS21 & Mean \\
\hline \multicolumn{9}{|l|}{ Broodstock } \\
\hline Sample size & 51 & 51 & 51 & 51 & 51 & 51 & 51 & \\
\hline No. of allele & 18 & 8 & 8 & 18 & 15 & 14 & 12 & 13.3 \\
\hline Observed $\left(H_{n}\right)$ & 0.882 & 0.745 & 0.784 & 0.922 & 0.823 & 0.902 & 0.863 & 0.846 \\
\hline Expected $\left(H_{e}\right)$ & 0.844 & 0.816 & 0.800 & 0.915 & 0.896 & 0.897 & 0.828 & 0.857 \\
\hline$\left(H_{o} / H_{e}\right)$ & 1.045 & 0.913 & 0.980 & 1.008 & 0.918 & 1.006 & 1.042 & 0.987 \\
\hline \multicolumn{9}{|l|}{2000 offspring } \\
\hline Sample size & 68 & 70 & 69 & 67 & 67 & 66 & 66 & \\
\hline No. of allele & 14 & 7 & 7 & 16 & 14 & 11 & 9 & 11.1 \\
\hline Observed (Ho) & 0.758 & 0.894 & 0.864 & 0.924 & 0.818 & 0.833 & 0.818 & 0.844 \\
\hline Expected $(\mathrm{He})$ & 0.857 & 0.834 & 0.795 & 0.881 & 0.857 & 0.886 & 0.773 & 0.840 \\
\hline$(\mathrm{Ho} / \mathrm{He})$ & 0.884 & 1.072 & 1.087 & 1.049 & 0.954 & 0.940 & 1.058 & 1.004 \\
\hline \multicolumn{9}{|l|}{2001 offspring } \\
\hline Sample size & 106 & 106 & 109 & 106 & 106 & 106 & 106 & \\
\hline No. of allele & 14 & 8 & 7 & 14 & 13 & 12 & 9 & 11.0 \\
\hline Observed $(\mathrm{Ho})$ & 0.853 & 0.873 & 0.794 & 0.892 & 0.902 & 0.922 & 0.745 & 0.854 \\
\hline Expected $(H e)$ & 0.833 & 0.831 & 0.781 & 0.853 & 0.858 & 0.886 & 0.783 & 0.832 \\
\hline$\left(H_{0} / H_{e}\right)$ & $1.024^{*}$ & 1.050 & 1.017 & 1.046 & 1.051 & 1.041 & $0.951^{*}$ & 1.027 \\
\hline
\end{tabular}

*Departure from Hardy-Weinberg equilibrium at $P<0.05$.

Allele frequencies presented in Appendix.

Table 3 Microsatellite discrimination power expressed by the exclusion probability $(Q)$, polymorphic information content $(P I C)$ and probability of identity index $(I)$

\begin{tabular}{|c|c|c|c|c|}
\hline \multirow[b]{2}{*}{ Locus } & \multicolumn{2}{|c|}{ Broodstock } & \multicolumn{2}{|c|}{ Offspring } \\
\hline & $Q$ & PIC & $I(2000)$ & $I(2001)$ \\
\hline ACS3 & 0.8803 & 0.823 & $3.637 \times 10^{-2}$ & $4.601 \times 10^{-2}$ \\
\hline$A C S 4$ & 0.8085 & 0.783 & $5.221 \times 10^{-2}$ & $5.359 \times 10^{-2}$ \\
\hline ACS6 & 0.7811 & 0.760 & $7.285 \times 10^{-2}$ & $7.755 \times 10^{-2}$ \\
\hline ACS9 & 0.9524 & 0.899 & $2.699 \times 10^{-2}$ & $3.975 \times 10^{-2}$ \\
\hline ACS16 & 0.9632 & 0.873 & $3.866 \times 10^{-2}$ & $3.585 \times 10^{-2}$ \\
\hline ACS17 & 0.9194 & 0.878 & $2.628 \times 10^{-2}$ & $2.118 \times 10^{-2}$ \\
\hline ACS21 & 0.8440 & 0.801 & $7.857 \times 10^{-2}$ & $7.433 \times 10^{-2}$ \\
\hline 2 loci & 0.9771 & & & \\
\hline 3 loci & 0.9950 & & & \\
\hline 4 loci & 0.9998 & & & \\
\hline 5 loci & $\sim 1$ & & & \\
\hline 6 loci & $\sim 1$ & & & \\
\hline 7 loci & $\sim 1$ & & & \\
\hline Mean & & 0.831 & $2.980 \times 10^{-10}$ & $4.290 \times 10^{-10}$ \\
\hline
\end{tabular}

respectively. These values resulted in a final $2.5 \%$ of inbreeding depression in 2000 and $5.6 \%$ in 2001 (Table 4).

\section{Stock separation}

A total of 199 previously released black sea bream juveniles were recaptured between 30 July and 28 September at Daio Bay in Ninoshima Island. On 30 July (first day after release, DAR), $76.9 \%$ of the samples represented stocked specimens. This percent changed to $25 \%$ on 7 August (ninth DAR), $70 \%$ on 22 August (24th DAR), $67.3 \%$ on 5 September (38th DAR), and $60 \%$ on 28 September (61st DAR). Consequently, stocked individuals accounted for $58.8 \%$ of the catch during the two months following the release date.

On the FL distribution of wild and hatchery stocks fish, no significant differences in either frequencies $(P<0.01$, F-ratio $)$ or lengths $(P<0.01$, Student's $t$-test) between hatchery and wild groups were evidenced (Fig. 2). In addition, the weightlength relationships indicated similar patterns $(P<0.01)$ for both groups: $\mathrm{BW}=0.016 \times \mathrm{FL}^{3.059}$ $\left(r^{2}=0.983\right)$ and BW $=0.017 \times \mathrm{FL}^{3.065}\left(r^{2}=0.967\right)$ in wild and hatchery stock, respectively (Fig. 3).

\section{DISCUSSION}

The proper management of individuals as broodstock is essential for stock enhancement. The Hiroshima City Marine Products Promotion Center used 51 black sea bream as broodstock to produce juveniles for stocking at Hiroshima Bay, releasing around 1 million seedlings annually. To understand the importance of this resource in the economy of the Prefecture, it is necessary to assess the contribution of the breeders as well as monitor possible effect of releasing their juveniles.

Using seven microsatellite DNA markers, $69.3 \%$ of the offspring were properly assigned to their true parents. The value is similar to the $73.5 \%$ reported for Pagrus major with only four microsatellite 
Table 4 Results of pedigree tracing and estimation of the inbreeding coefficient in 2000 and 2001

\begin{tabular}{lrr}
\hline & \multicolumn{2}{c}{ Offspring } \\
\cline { 2 - 3 } Matching to & 2000 & 2001 \\
\hline One parental couple & $46(69.7 \%)$ & $69(69.0 \%)$ \\
Two or more parental couples & $13(19.7 \%)$ & $23(23.0 \%)$ \\
One parent alone & $6(9.1 \%)$ & $6(6.0 \%)$ \\
One sex couple & $1(1.5 \%)$ & $2(2.0 \%)$ \\
Number of families observed & $36(5.6 \%)$ & $40(6.3 \%)$ \\
Number of contributors & & $14(48.2 \%)$ \\
$\quad$ Female $(N f)$ & $15(51.7 \%)$ & $16(72.7 \%)$ \\
Male $(N m)$ & $17(77.2 \%)$ & $30(58.8 \%)$ \\
Total & $32(62.7 \%)$ & 29.9 \\
$N e$ (unequal sex proportion) $=4 \times N f \times N m /(N f+N m)$ & 31.9 & 13.1 \\
Variance of offspring per parent & & 9.8 \\
$\quad$ Per female $\left(V_{k f}\right)$ & 3.9 & 8.9 \\
$\quad$ Per male $\left(V_{k m}\right)$ & 5.0 & 0.056
\end{tabular}

(a)

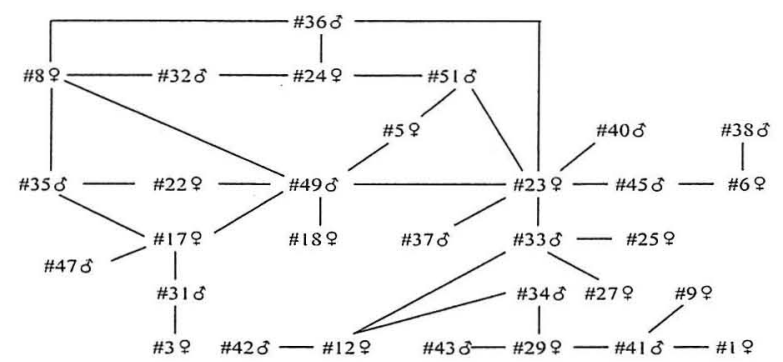

(b)

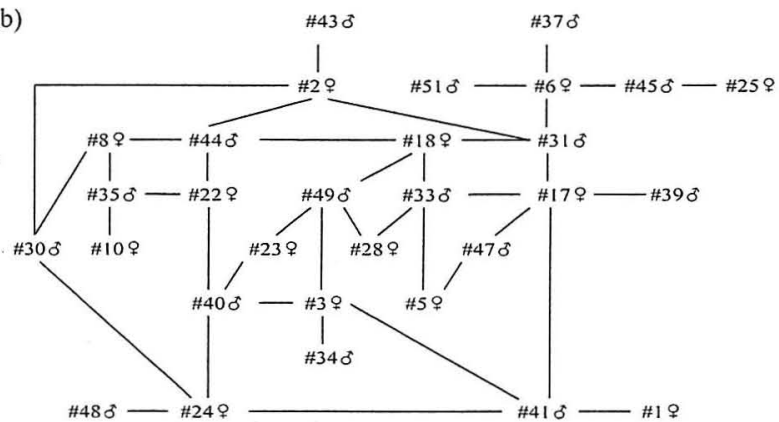

Fig. 1 Reconstructed mating model of candidate parent black sea bream in (a) 2000 and (b) 2001 using seven microsatellite loci. Specimen numbers for individual fish are shown.

DNA markers. ${ }^{15}$ However, the success in matching broodstock-offspring of these two sparidae are lower than those reported in Atlantic halibut Hippoglossus hippoglossus or Japanese flounder Paralichthys olivaceus. ${ }^{8,16}$ In both flatfish species, the number of locus and alleles scored fewer mating broodstock, and were similar to those obtained in the present study. Despite the strong discrimination ability screened by the seven loci,

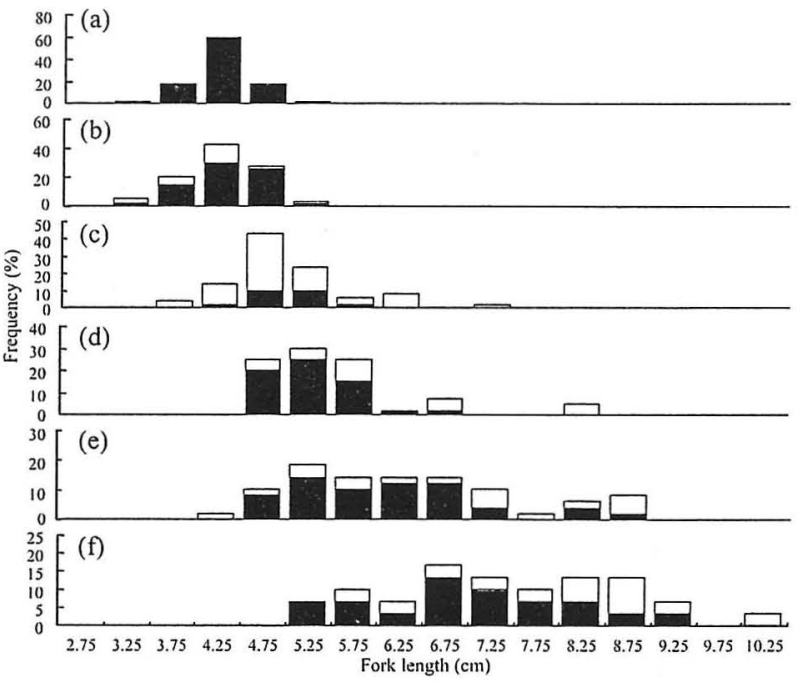

Fig. 2 Changes in fork length (cm) distribution between hatchery ( $\square$ ) and wild ( $\square$ ) black sea bream for (a) hatchery stock, and on (b) 30 July 2001, first day after release (DAR), (c) 7 August, eighth DAR, (d) 22 August, 23rd DAR, (e) 5 September, 37th DAR, and (f) 28 September, 61st DAR.

the use of extra loci with hyperpolymorphism is necessary in order to assign all offspring to a single parent couple.

In 2000, 36 families were comprised of $62.7 \%$ ( 32 fish) of the breeders, rising to 40 families from $58.8 \%$ (30 fish) in 2001. Offspring were assigned to $90.9 \%$ of the sires, in contrast to only $69 \%$ of the dams within the two years. In Japanese flounder, 50 and $57 \%$ of the broodstock were observed to contribute into the mating process. ${ }^{7,16}$ However, a single sire contributed to $99 \%$ of offspring production. ${ }^{16}$ 


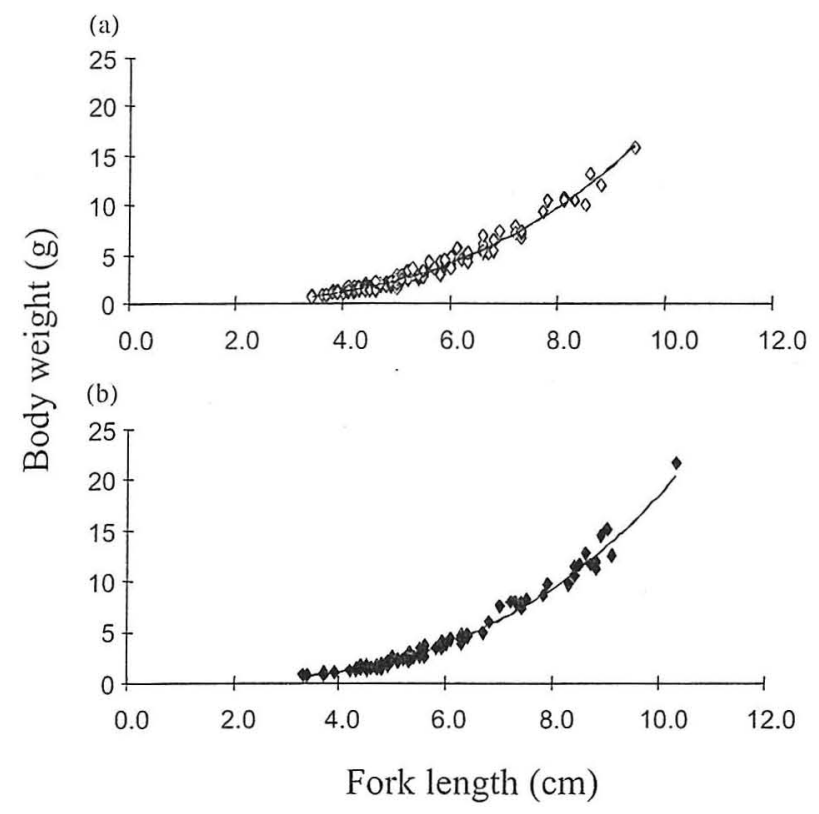

Fig. 3 Relationships between fork length $(\mathrm{cm})$ and body weight ( $\mathrm{g}$ ) of (a) wild $(\diamond)$ and (b) hatchery $(\diamond)$ black sea bream after release. Wild $\mathrm{BW}=0.016 \times \mathrm{FL}^{3.059}$, $R^{2}=0.983$; hatchery $\mathrm{BW}=0.017 \times \mathrm{FL}^{3.065}, R^{2}=0.967$.

Working on black sea bream, Taniguchi et $a{ }^{5}{ }^{5}$ reported that only $15-25 \%$ of the 102 breeders contributed to the first offspring generations based on the analysis of 42 isozyme loci. In their results, ${ }^{5}$ the percent of candidates for mating was much lower than that observed in the present study. An explanation for the difference in contribution rate might be reflected in the discrimination power of the markers between isozyme and microsatellites. Other factors may be attributed to difference in background and rearing techniques of breeders. For instance, Taniguchi et al. ${ }^{5}$ observed the mating process using only wild captive black sea bream. In contrast, our observation was conducted with a mix of hatchery and wild captive fish. Further, imperfect dietary or nutritional conditions for broodstock in the 1980s might have negative effects for reproduction.

The proportion of candidate breeders for reproduction in the present study is also much higher than the $30 \%$ reported in red sea bream. ${ }^{15}$ This difference may be reflected in mating behavior in sparidae species. Mating in red sea bream takes place in the evening, postponed to around midnight in black sea bream. Nocturnal mating might have the advantage of reducing artificial stress in hatchery conditions.

Variations in the family sizes reduced the final effective population sizes $(\mathrm{Ne})$ to 19.8 and 8.9 in 2000 and 2001, respectively. These values are much lower than the minimum 50 suggested by $\mathrm{FAO}^{28}$ to maintain genetic diversity in short-term programs. Using 250 individuals as broodstock, the final $\mathrm{Ne}^{*}=63.7$ that was scored in red sea bream ${ }^{15}$ reflects the necessity of using large numbers of breeders to maintain genetic diversity. At the other extreme, $N e^{*}=3.3$ in Japanese flounder, ${ }^{16}$ confirming the negative consequences of mating low numbers of individuals and the potential risk of genetic drift in case of stocking juveniles into natural conditions.

The small effective population sizes obtained for black sea bream caused a final inbreeding depression of 2.5 and 5.5\% in 2000 and 2001, respectively. This problem was already detected in the three flatfish species, Atlantic halibut, ${ }^{8}$ Japanese flounder, ${ }^{16}$ and barfin flounder. ${ }^{29}$ Alarcón et al. ${ }^{12}$ remarked that protandric hermaphrodite species tend to present lower effective population sizes, increasing the inbreeding depression. In red sea bream, the final inbreeding level using 250 breeders was $0.8 \%,{ }^{24}$ suggesting that few broodstock, in addition to founder effects, are the main factors producing inbreeding problems observed in black sea bream.

Norris et $a l .{ }^{6}$ referred to the small population size and poor management practices as the main factors to explain the loss of genetic diversity in hatchery strains. Taniguchi et al. ${ }^{5}$ pointed out the loss of genetic diversity detected by heterozygosity levels through parentage analysis using allozyme markers. ${ }^{5}$ However, parameters for loss of genetic diversity using microsatellite markers may be reflected in the allelic diversity. Black sea bream presented similar levels of heterozygosity as other marine fish species, ${ }^{7,13,30}$ and remarkable losses of alleles (e.g. $16.9 \%$ ) in the present study was evident with unchanged heterozygosity. In contrast to red sea bream, ${ }^{24}$ using the same one-day egg collection method, no reduction in the frequencies of the major alleles was observed. Although it should be carefully monitored, this finding might indicate there are no limitations of this methodology in our target species.

In the present study, average recapture rate accounted for $58.8 \%$ of the catch during the two months after release at Daio Bay in Ninoshima Island. This level had already been documented using external tags. ${ }^{2,3}$ However, the rates in the two initial recapture trials fluctuated from $25 \%$ at the ninth to $76.9 \%$ at the first DAH. We observed that after release, hatchery fish formed their own school separate from the wild fish. This behavior might lead to maldistribution and distortion in recapture rates between wild and hatchery fish. Recapture rates stabilized after the 24 th DAR (e.g. $70 \%$ at 24 th, $67.3 \%$ at 38 th, and $60 \%$ at 61 st DAR), suggesting the schools blended when the hatchery fish acclimated to the new environment. 
In Japan, great effort has been made to improve hatchery production, despite scarce data available regarding the effectiveness of the stocking programs. $^{31}$ In Kagoshima Bay, ${ }^{1,31}$ stocked red sea bream represented $54 \%$ of the commercial landings. Imai ${ }^{32}$ reported only $8-12 \%$ of specimens were hatchery stock in Kanagawa Prefecture. However, there is evidence that released red sea bream could not be identified in Kochi Prefecture. ${ }^{24}$ In Australia, $12 \%$ of sampled Acanthopagrus butcheri was identified as hatchery origin. ${ }^{33}$ Very low recapture rates were also reported in Sparus aurata, the main sparidae species for aquaculture in Mediterranean countries. ${ }^{34}$ The congruence of several factors such as good release techniques, fast metabolic adaptation, species ability to remain in the releasing and/or birth place, low fishing pressure, and high nutritional levels at the release area seem to explain the high survival of black sea bream in Hiroshima Bay. The similarities in the growth and size distribution between released and wild fish may partly support these hypotheses.

This experience demonstrates that black sea bream represents a very interesting species for stocking, with fast acclimation to the natural environment. Alarcón et al..$^{12}$ found that the success of gilthead sea bream Sparus aurata for aquaculture resided in the high levels of heterozygosity derived from the combination of molecular, demographic, and evolutionary factors. The results obtained in the present study might also confirm the success of black sea bream for domestication. However, the loss of alleles and the inbreeding problems derived from low numbers of breeders suggest the necessity to reconsider the stocking strategy. Increasing the number of breeders, collecting eggs from different days, and a posterior long-term genetic monitoring assessment might contribute to reduce the genetic drift. It would help to understand the reproductive behavior of this species in order to properly manage the fishery of this important resource in Hiroshima Bay. Considering the importance of stocking programs in Japan and the low number of successful cases reported, ${ }^{1}$ the results obtained in this study are a useful insight into black sea bream.

\section{ACKNOWLEDGMENTS}

Thanks to Hiroshima City Marine Products Promotion Association for providing specimens used in the present study. The present study was supported by a Grant-in-Aid for Scientific Research (C) from the Japan Society for the Promotion of Science (JSPS) to T.U. (No. 14560152).

\section{REFERENCES}

1. Fushimi H. Production of juvenile marine finfish for stock enhancement in Japan. Aquaculture 2001; 200: 33-53.

2. Yamashita $H$, Umino $T$, Nakahara $S$, Okada $K$, Nakagawa $H$. Changes in some properties of black sea bream released into the Daio Bay. Fish. Sci. 1997; 63: 267-271.

3. Umino T, Hayashi M, Miyatake J, Nakayama K, Sasaki T, Okada K, Nakagawa H. Significance of release of black sea bream at 20-mm size on stock enhancement in Daiô Bay, Hiroshima. Suisanzoshoku 1999; 47: 337-342.

4. Nakagawa H, Umino T, Hayashi M, Sasaki T, Okada $K$. Changes in biochemical composition of black sea bream released at $20 \mathrm{~mm}$ size in Daio Bay, Hiroshima. Suisanzoshoku 2000; 48: 643-648.

5. Taniguchi N, Sumantadinata K, Iyama S. Genetic Change in the first and second generations of hatchery stock of black seabream. Aquacultule 1983; 35: 309-320.

6. Norris AT, Bradley DG, Cunningham EP. Microsatellite genetic variation between and within farmed and wild Atlantic salmon (Salmo salar) populations. Aquaculture 1999; 180: 247-264.

7. Hara M, Sekino M. Efficient detection of parentage in a cultured Japanese flounder Paralichthys olivaceus using microsatellite DNA marker. Aquaculture 2003; 217: 107114.

8. Jackson TR, Martin-Robichaud DJ, Reith ME. Application of DNA markers to the management of Atlantic halibut (Hippoglossus hippoglossus) broodstock. Aquaculture 2003; 220: 245-259.

9. Nugrohoa E, Taniguchi N. Daily change of genetic variability in hatchery offspring of red sea bream during spawning season. Fish. Sci. 2004; 70: 638-644.

10. Allendorf FW, Phelps SR. Loss of genetic variation in a hatchery stock of cutthroat trout. Trans. Am. Fish. Soc. 1980; 109: $537-543$

11. Jeong DS, Umino T, Kuroda K, Hayashi M, Nakagawa $H$, Kang JC, Morishima K, Arai K. Genetic divergence and population structure of black sea bream Acanthopagrus schlegeli inferred from microsatellite analysis. Fish. Sci. 2003; 69: 896-902.

12. Alarcón JA, Magoulas A, Georgakopoulos T, Zouros E, Alvarez MC. Genetic comparison of wild and cultivated European populations of the gilthead sea bream (Spartus autata). Aquaculture 2004; 230: 65-80.

13. De Innocentiis S, Lesti A, Livi S, Rossi AR, Crosetti D, Sola L. Microsatellite markers reveal population structure in gilthead sea bream Sparus autatus from the Atlantic Ocean and Mediterranean Sea. Fish. Sci. 2004; 70: 852-859.

14. O'Reilly PT, Herbinger C, Wright JM. Analysis of parentage determination in Atlantic salmon (Salmo salar) using microsatellites. Anim. Genet. 1998; 29: 363-370.

15. Perez-Enriquez R, Takagi M, Taniguchi N. Genetic variability and pedigree tracing of a hatchery-reared stock of red sea bream (Pagrus major) used for stock enhancement, based on microsatellite DNA markers. Aquaculture 1999; 173: $413-423$.

16. Sekino M, Saitoh $K$, Yamada T, Atsushi $K$, Motoyuki $H$, Yamashita Y. Microsatellite-based pedigree tracing in a Japanese flounder Paralichthys olivaceus hatchery strain: implications for hatchery management related to stock enhancement program. Aquaculture 2003; 221: 255-263. 
17. Taggart JB, Hynes RA, Prodohl PA, Ferguson A. A simplified protocol for routine total DNA isolation from salmonid fishes. J. Fish. Biol. 1992; 40: 963-965.

18. Raymond M, Rousset F. GENEPOP (version 3.4): population genetics software for exact tests and ecumenicism. J. Hered. 1995; 86: 48-249.

19. Guo SW, Thompson EA. Performing the exact test of HardyWeinberg proportions for multiple alleles. Biometrics 1992; 48: 361-372.

20. Schneider S, Roessli D, Excoffier L. Arlequin, ver. 2.0: A Software for Population Genetic Data Analysis. Genetics and Biometry Laboratory, University of Geneva, Geneva. 2000.

21. Botstein D, White RL, Skolnick M, Davis RW. Construction of a genetic linkage map in man using restriction fragment length polymorphisms. Am. J. Hum. Gen. 1980; 32: 314-331.

22. Marshall TC, Slate J, Kruuk LEB, Pemberton JM. Statistical confidence for likelihood-based paternity inference in natural populations. Mol. Ecol. 1998; 7: 639-655.

23. Villanueva B, Verspoor E, Visscher PM. Parental assignment in fish using microsatellite genetic markers with finite numbers of parents and offspring. Anim. Genet. 2002; 33: 33-41.

24. Perez-Enriquez R, Taniguchi N. Use of microsatellite DNA as genetic tags for the assessment of a stock enhancement program of red sea bream. Fish. Sci. 1999; 65: 374-379.

25. Duchesne P, Godbout MH, Bernatchez L. PAPA (package for the analysis of parental allocation): a computer program for simulated and real parental allocation. Mol. Ecol. Notes 2002; 2: 191-193.

26. Crow JF, Kimura MA. An Introduction to Population Genetics Theory. Harper \& Row, London. 1970.

27. Hill WG. A note on effective population size with overlapping generations. Genetics 1979; 92: 317-322.

28. FAO/UNEP. Conservation of the genetic resources of fish: problems and recommendations. Report of the Expert Consultation on the genetic resources of fish. Rome, FAO. Fish. Tech. Paper no. 217. Food and Agriculture Organization of the United Nations, Rome, Italy. 1981.

29. Ortega-Villaizán Romo MM, Suzuki S, Ikeda M, Nakajima $M$, Taniguchi N. Monitoring of the genetic variability of the hatchery and recaptured fish in the stock enhancement program of the rare species barfin flounder Verasper moseri. Fish. Sci. 2005; 71: 1120-1130.

30. Bentzen P, Taggart CT, Ruzzante DE, Cook D. Microsatellite polymorphism and the population structure of Atlantic cod (Gadus morhua) in the northwest Atlantic. Can. J. Fish. Aquat. Sci. 1996; 53: 2706-2721.

31. Kitada S. Effectiveness of Japan's stock enhancement programs: current perspectives. In: Howell BR, Mokness E, Svasand T (eds). Stock Enhancement and Sea Ranching. Fishing News Books, Oxford. 1999; 103-131.

32. Imai T. Estimates of return rates of red sea bream seeds released in Kanagawa Prefecture. Saibai Giken Tokyo 1996; 25: 59-74.

33. Lenanton RC, Ayvazian SG, Dibden C, Jenkins G, Sarre G. The use of stock enhancement to improve he catch rates of black bream, Acanthopagrus butcheri (Munro) from Western Australian recreational fishers. In: Howell BR, Mokness E, Svasand T (eds). Stock Enhancement and Sea Ranching. Fishing News Books, Oxford. 1999; 219-230.

34. Sánchez-Lamadrid A. Effectiveness of releasing gilthead sea bream (Sparus aurata, L.) for stock enhancement in the bay of Cádiz. Aquaculture 2004; 231: 135-148.

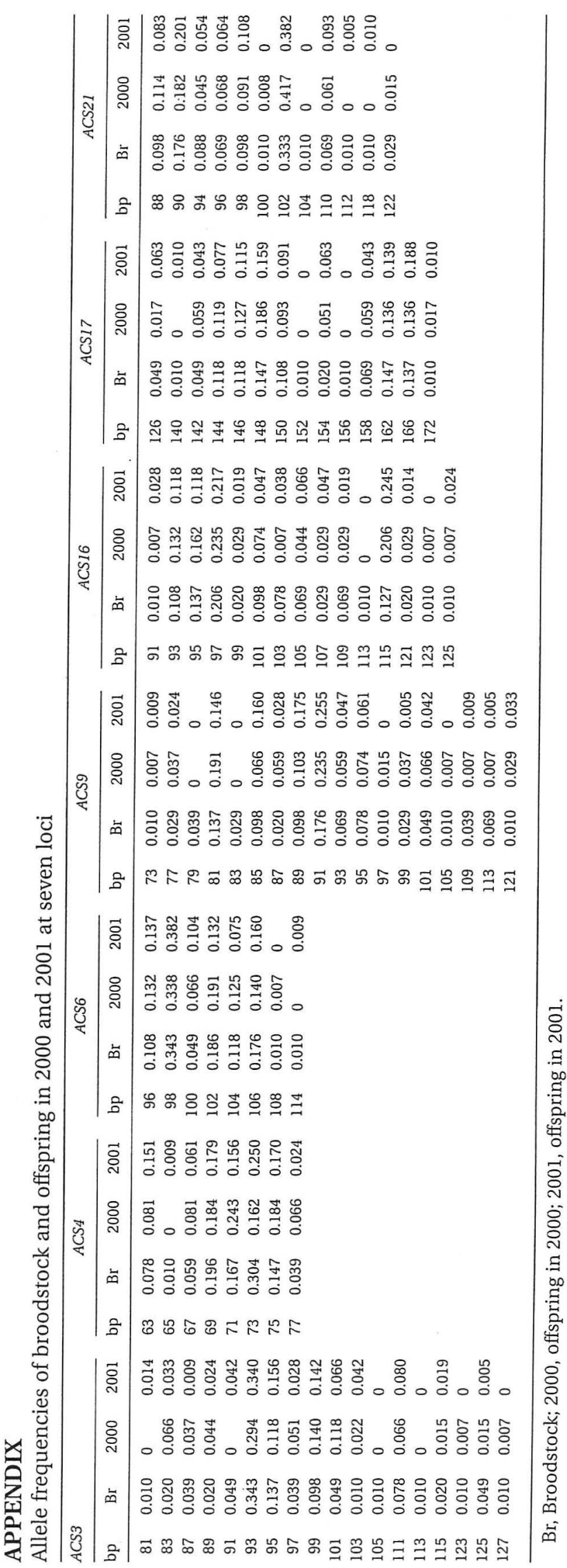

